\title{
Effect of physical activity on the sequelae of osteoporosis in female residents of residential care facilities
}

\author{
Agnieszka J. Nawrat-Szołtysik ${ }^{1,2, A-D, F}$, Anna Polak ${ }^{3, B, C}$, Andrzej Małecki ${ }^{4, C, E}$, Laura Piejk0 ${ }^{5, B}$, \\ Dominika Grzybowska-Ganszczyk ${ }^{5, B}$, Michał Kręcichwost ${ }^{6, B, C}$, Józef Opara ${ }^{4, A, E, F}$ \\ 1 Department of Health Promotion and Methodology of Research, The Jerzy Kukuczka Academy of Physical Education in Katowice, Poland \\ 2 St. Elizabeth Center, Ruda Śląska, Poland \\ ${ }^{3}$ Department of Basic Physical Therapy, The Jerzy Kukuczka Academy of Physical Education in Katowice, Poland \\ ${ }^{4}$ Department of Nervous System and Musculoskeletal System, The Jerzy Kukuczka Academy of Physical Education in Katowice, Poland \\ ${ }^{5}$ The Jerzy Kukuczka Academy of Physical Education in Katowice, Poland \\ ${ }^{6}$ Department of Biomedical Engineering, Silesian University of Technology, Zabrze, Poland \\ A - research concept and design; $B$ - collection and/or assembly of data; $C$ - data analysis and interpretation; \\ $D$ - writing the article; $E$ - critical revision of the article; $F$ - final approval of the article
}

Address for correspondence

Aleksandra Nawrat-Szołtysik

E-mail: a.nawrat-szoltysik@awf.katowice.pl

Funding sources

None declared

Conflict of interest

None declared

Received on February 17, 2016

Reviewed on August 18, 2016

Accepted on January 10, 2017

D0I

10.17219/acem/68381

Copyright

Copyright by Author(s)

This is an article distributed under the terms of the

Creative Commons Attribution Non-Commercial License

(http://creativecommons.org/licenses/by-nc-nd/4.0/)

\begin{abstract}
Background. Osteoporosis is one of the most common diseases that develop with age and cause high morbidity and mortality among elderly people.

Objectives. This study was set out to evaluate the influence of a program of modified Sinaki exercises, Nordic walking (NW) and a combination of these physical activities on people with osteoporosis.

Material and methods. A sample consisting of 91 women aged 65-98 years living in residential care facilities was randomized into 4 groups. The control group (group 1) received only pharmacological treatment. In the other 3 groups, the same drug therapy was enhanced by a program of modified Sinaki exercises (group 2), Nordic walking (group 3), and Sinaki exercises and Nordic walking applied together (group 4). At baseline and after 12 months of intervention, the participants were assessed for bone density, rib cage mobility, motor abilities, risk of falling (Timed Up and Go Test - TUG, Functional Reach Test - FRT), and locomotor activity (based on pedometer readings). The intervention was completed by 83 participants.
\end{abstract}

Results. Bone density (T-score) was higher in all intervention groups and in the control group $(p<0.003)$. The improvement in rib cage mobility was statistically significant in groups $2(p<0.001)$ and $4(p<0.002)$. Locomotor activity significantly improved in groups $3(p<0.000)$ and $4(p<0.000)$. The post-intervention results of the TUG and FRT tests showed a significantly lower risk of falling in group 4. In groups 1 and 2, the risk was higher, but not statistically significantly, and in group 3 , it did not change.

Conclusions. Modified Sinaki exercises and Nordic walking significantly improved the mobility of the rib cage, locomotor activity and motor abilities in the women comprising groups 2 and 3 , but the best results of the intervention were noted in the group treated with both forms of physical activity.

Key words: physical activity, osteoporosis, Nordic walking, elderly people 


\section{Introduction}

Osteoporosis is one of the most common diseases which develop with age and contribute to high morbidity and mortality rates among the elderly. Its symptoms include postural deformities, pain and disorders of the alimentary canal and breathing function. Falls resulting in lowenergy fractures are as much a symptom as a consequence. It is estimated that up to $10-25 \%$ of falls reported by residents of residential care facilities (RCFs) and hospitals lead to fractures, triple the rate of that for people living in the home environment. ${ }^{1}$

Osteoporosis is easier to prevent and diagnose than to treat, particularly when advanced. Using drugs alone is not an effective therapy, unlike a comprehensive approach consisting of pharmacological treatment, appropriate dietary intervention and physical activity. ${ }^{2}$ One of the most useful physical activities in the case of osteoporotic patients is walking, during which the musculoskeletal system counteracts gravitational forces. The alternate contraction and relaxation of the muscles strengthens them and improves the bone resorption-to-formation ratio. ${ }^{3}$ One type of walking activity that is becoming increasingly popular is Nordic walking (NW), i.e., walking with a pair of sticks similar to those used in cross-country skiing. How exactly Nordic walking benefits people with osteoporosis is yet to be established, but it is already known to be an effective means of rehabilitation and recreation for elderly people. ${ }^{4,5}$ The survey of 100 students of the Third Age University conducted by Morgulec-Adamowicz et al. has indicated that an increasing number of elderly people are taking an interest in pole-assisted walking. ${ }^{6}$ There is evidence that doing carefully selected physical exercises on a regular basis can increase bone mass density (BMD) in young people and prevent its reduction in the elderly. ${ }^{7}$ Physical exercises have also been found to improve osteoporotic patients' mobility and to alleviate their pain, thus raising their quality of life. The range of physical exercises that can be effectively used to manage osteoporosis includes atypical movements that stretch, flex and twist the musculoskeletal system, and combinations thereof. A good example would be isometric and resistance exercises that make the bones cope with loads different from those related to regular daily activities. ${ }^{8-10}$

One of the first programs of physical exercises addressing the needs of people with osteoporosis was created at the Mayo Clinic, USA, by Mehrsheed Sinaki in 1982. Three years later, similar programs were compiled by Goodman, and by Simkin and Aylon. In 1987, the existing exercises were modified and standardized by Steinberg. ${ }^{8,9}$ The Sinaki exercises are performed in a prone or supine position, a hands-and-knees position, while sitting in a chair, or on the floor with legs extended forward. The whole set of exercises can be completed in around 40 min. ${ }^{11}$

In this study, the exercise positions proposed by Sinaki were modified by reducing their number to 1 sitting position that was easy and safe for elderly females. ${ }^{12}$
The purpose of the study was to evaluate the effect of programs containing modified Sinaki exercises, Nordic walking and a combination of these 2 activities on people with osteoporosis.

The specific research goals of the study were the following:

- to assess the effect of modified Sinaki exercises on bone density, rib cage mobility, locomotor activity, motor abilities, and the risk of a fall in elderly women with reduced bone mass;

- to assess the influence of Nordic walking on these variables;

- and to assess the joint effect of modified Sinaki exercises and Nordic walking on these variables.

\section{Material and methods}

The study protocol was approved by the Bioethics Commission at the Academy of Physical Education in Katowice (decision No. 7/2009).

The selection of the study participants was performed based on a set of inclusion and exclusion criteria. The qualifying females had to submit written consent to participate in the study.

\section{Selection of the sample}

The study participants were women staying in 4 residential care facilities: 2 in Ruda Śląska, 1 in Katowice and 1 in Tychy.

The inclusion criteria were as follows:

- osteoporosis and osteopenia confirmed by densitometry (T-score $\leq-1.0)$;

- age $\geq 65$ years;

- the ability to understand the purpose of the study;

- pharmacological treatment for osteoporosis or osteopenia.

The exclusion criteria included:

- unconfirmed osteoporosis or osteopenia (T-score >-1.0);

- age $<65$ years;

- reluctance to cooperate;

- problems with understanding the purpose of the study;

- not receiving pharmacological treatment for osteoporosis or osteopenia.

Of the 131 women aged $65-98$ years who were initially screened, 91 were enrolled in the study. They were randomized into 3 intervention groups and a control group, all receiving the same pharmacological therapy. Group 1 ( $\mathrm{n}=24$ ) was a control, "drugs-only" group $(\mathrm{C})$. The other 3 groups were additionally administered the following types of physical activity:

- group $2(n=23)(E X)$ - modified Sinaki exercises (sessions on Mondays and Thursdays);

- group $3(\mathrm{n}=21)(\mathrm{NW})$ - Nordic walking (sessions on Tuesdays and Fridays); 
- group $4(\mathrm{n}=23)(\mathrm{EX}+\mathrm{NW})$ - a combination of the above activities (modified Sinaki exercises on Mondays and Thursdays and Nordic walking on Tuesdays and Fridays).

The study spanned a period of 12 months. By the end of that period, the group had diminished to 83 women (20 in group 1 and 21 in each of the other 3 groups) for reasons such as death $(n=4)$, major health problems $(n=2)$ and voluntary withdrawal $(\mathrm{n}=2)$ (Fig. 1).

\section{Research methods}

The participants were examined at baseline, and then after 12 months of physical exercises. The following methods were used for measurement:

- bone densitometry - forearm bone density was measured with a peripheral DXA scanner (PIXI, GE Medical Systems Lunar, Madison, USA); the Least Significant Change (LSC) was 2.9;

- measurement of the circumferences of the participants' chests at max inhalation and max exhalation to determine rib cage mobility (with a measuring tape $[\mathrm{cm}]$ );
- the Timed Up and Go Test (TUG) evaluating the participants' mobility and risk of falling by measuring the time needed to rise from sitting in a chair, walk $3 \mathrm{~m}$ along a line, return to the chair, and sit down. In this study, the height of the chair $(46 \mathrm{~cm})$ was the same as that used by Siggeirsdóttir et al. ${ }^{13}$ The measure of a participant's performance was the average time obtained from 2 trials. According to Żak, an elderly person capable of completing the test in $20 \mathrm{~s}$ has good motor abilities and can get up and sit down unaided. ${ }^{14}$ Times longer than $20 \mathrm{~s}$ indicate an increased risk of falling;

- the Functional Reach Test (FRT) evaluating postural balance and the risk of falling. In the test, a person stands sideways to the wall with the pelvis and 1 arm touching it, and raises that arm to $90^{\circ}$. The tip of the middle finger having been marked on the wall, the person leans forward as far as possible without moving their feet and pelvis, and the tip of the same finger is marked on the wall again. The distance between the 2 marks determines a patient's performance on the test. In this study, the average of 2 trials was used to evaluate the participants. As in other

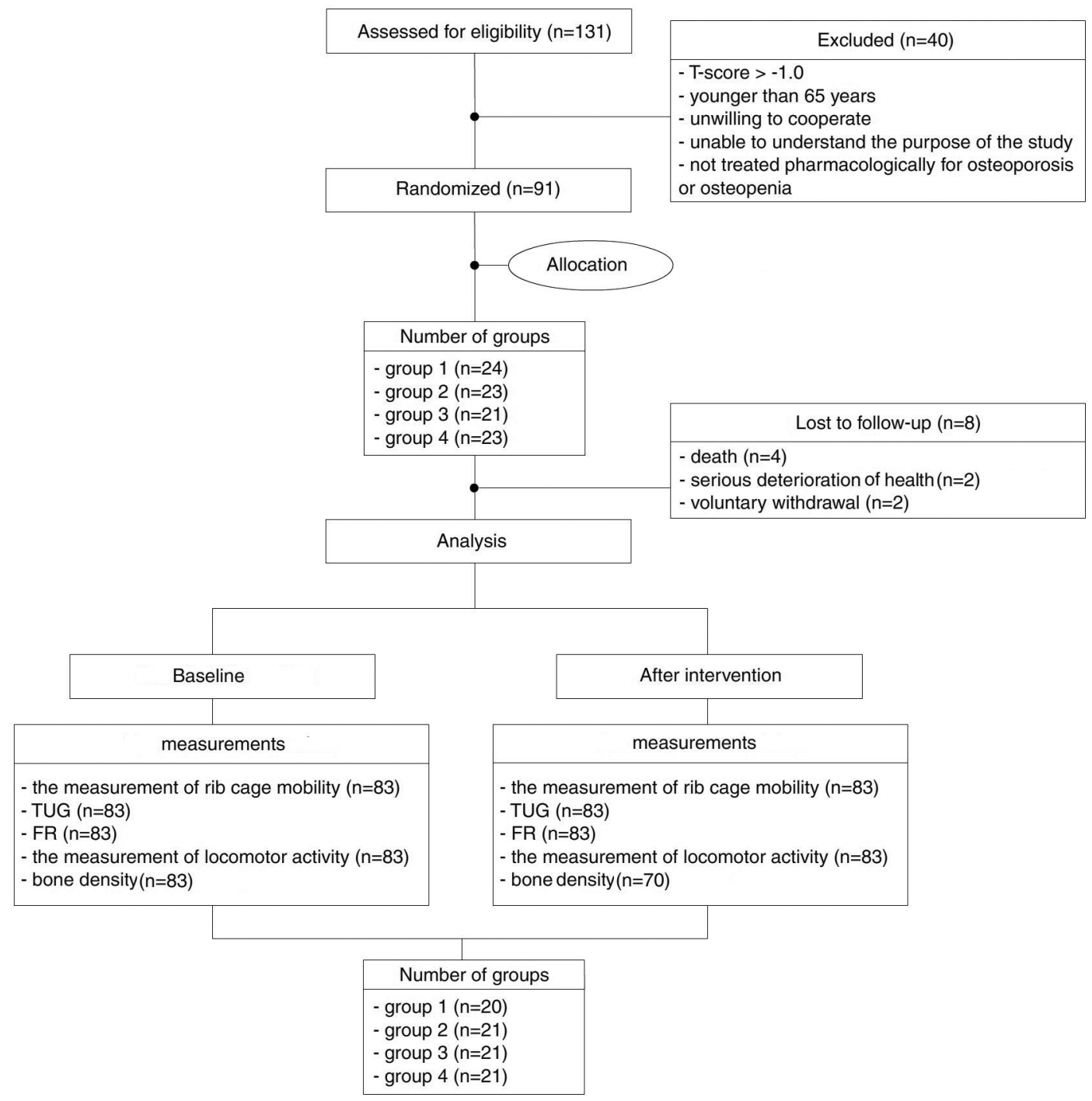

Fig. 1. Flow diagram of the study 
studies, it was assumed that a distance smaller than $25 \mathrm{~cm}$ was indicative of a higher risk of falling;

- the measurement of the participants' locomotor activity with Yamax Digi-Walker pedometers (Yamax Health \& Sport Inc., San Antonio, USA). The pedometers were clipped to the participants upon leaving bed in the morning and were removed before night rest. The participants wore the pedometers for a total of 14 days, i.e., 7 days before the study and 7 days after it ended. According to TudorLocke, chronically ill and disabled people aged 65 and older should take 3,500-5,500 steps a day. ${ }^{15}$

\section{Modified Sinaki exercises}

Sessions of modified Sinaki exercises started with a warmup followed by stretching, isometric and body resistance exercises, resistance exercises involving the use of a flexible band, abdomen and back strengthening exercises, and relaxation exercises.

The participants exercised in a sitting position twice a week for 12 months. Exercises were done to music, and various accessories were used to make them more interesting. On warm days, participants exercised outdoors. Researchers stress that the exercises need to be done on a regular basis, because each time they are discontinued or done with lower intensity, bone mass density returns to its baseline values. ${ }^{16}$

\section{Nordic walking}

Nordic walking is a brisk walk during which specially designed sticks engaging the shoulder girdle muscles are used. In the study, the NW group exercised, weather permitting, twice a week on flat terrain for a period of 12 months. Exercise intensity was set to $70 \%$ of the participants' max heart rate, and walking speed was $2-3 \mathrm{~km} / \mathrm{h}$. During Nordic walking, pedometers were not used.

A single NW session consisted of:

- a 5-10 min warm-up including stretching and breathing exercises to enable the participants to exercise at higher intensity and to reduce the risk of injuries;

- a 30 min walk, the duration of which was increased by $5 \mathrm{~min}$ (16\%) every 3 months, finally amounting to $45 \mathrm{~min}$;

- a relaxation phase for restoring and stabilizing normal cardiorespiratory function in the participants.

\section{Statistical analysis}

The statistical analysis started with the calculation of basic descriptive statistics, such as arithmetic averages, medians, standard deviations (SD), and kurtosis (Ku) and skewness (Sk) of the distributions. Their values were tested for normal distribution using the Kolmogorov-Smirnov test. Those found to have normal distributions were analyzed with parametric tests.
In order to determine if modified Sinaki exercises and/ or Nordic walking caused changes in the participants' bone density, rib cage mobility, motor abilities, locomotor activity, or risk of falling, the repeated factor (the results of pre- and post-intervention measurements) and the grouping factor (the type of therapy) were analyzed with 2-way repeated-measure ANOVA. When the effect of the order of examination (the difference between the results of pre- and post-intervention measurements), the effect of a therapy, or the effect of interaction between therapies were statistically significant, the intergroup differences were tested with Bonferroni's post-hoc test to find out which therapy was statistically significant.

Statistical analysis was performed using STATISTICA v. 10 software (StatSoft, Tulsa, USA). The level of statistical significance was accepted at $\mathrm{p}<0.05$.

\section{Results}

\section{The equivalence of the groups}

ANOVA showed that the study groups were not significantly different at baseline in mean age $(\mathrm{f}=0.123 ; \mathrm{p}=0.95)$, BMI ( $\mathrm{f}=2.09 ; \mathrm{p}=0.11$ ), T-score $(\mathrm{f}=1.56 ; \mathrm{p}=0.2$ ), or the length of residence at an RCF ( $f=0.39 ; \mathrm{p}=0.76)$.

The participants ranged in age from 65 to 98 years (the mean age was 81 years). Their mean BMI and mean bone density were 26.9 and -3.3 , respectively. The average length of residence at an RCF was 4.7 years.

\section{The effect of intervention on bone density}

Bone density measurements were made post-intervention in 60 participants (16 in group 1, 19 in group 2, 11 in group 3, and 14 in group 4). Because of health problems, 23 females did not appear for examination (Fig. 1). Bone densitometry showed that bone mass density had increased in all exercise groups, as well as in the control group (T-score) (Fig. 2).

ANOVA indicated that the effect of the order of examination was statistically significant $(\mathrm{p}<0.003)$ (Table 1$)$.

\section{The effect of intervention on rib cage mobility}

Rib cage mobility improved from baseline in all exercise groups, but in the control group it deteriorated (Fig. 3). ANOVA showed that both the effect of the order of examination $(\mathrm{p}<0.000)$ and the effect of interaction $(\mathrm{p}<0.004)$ were statistically significant (Table 1 ).

The results of Bonferroni's post-hoc test pointed to statistically significantly better rib cage mobility in groups 2 ( $\mathrm{p}<0.001)$ and 4 ( $\mathrm{p}<0.002)$ (Fig. 3). 

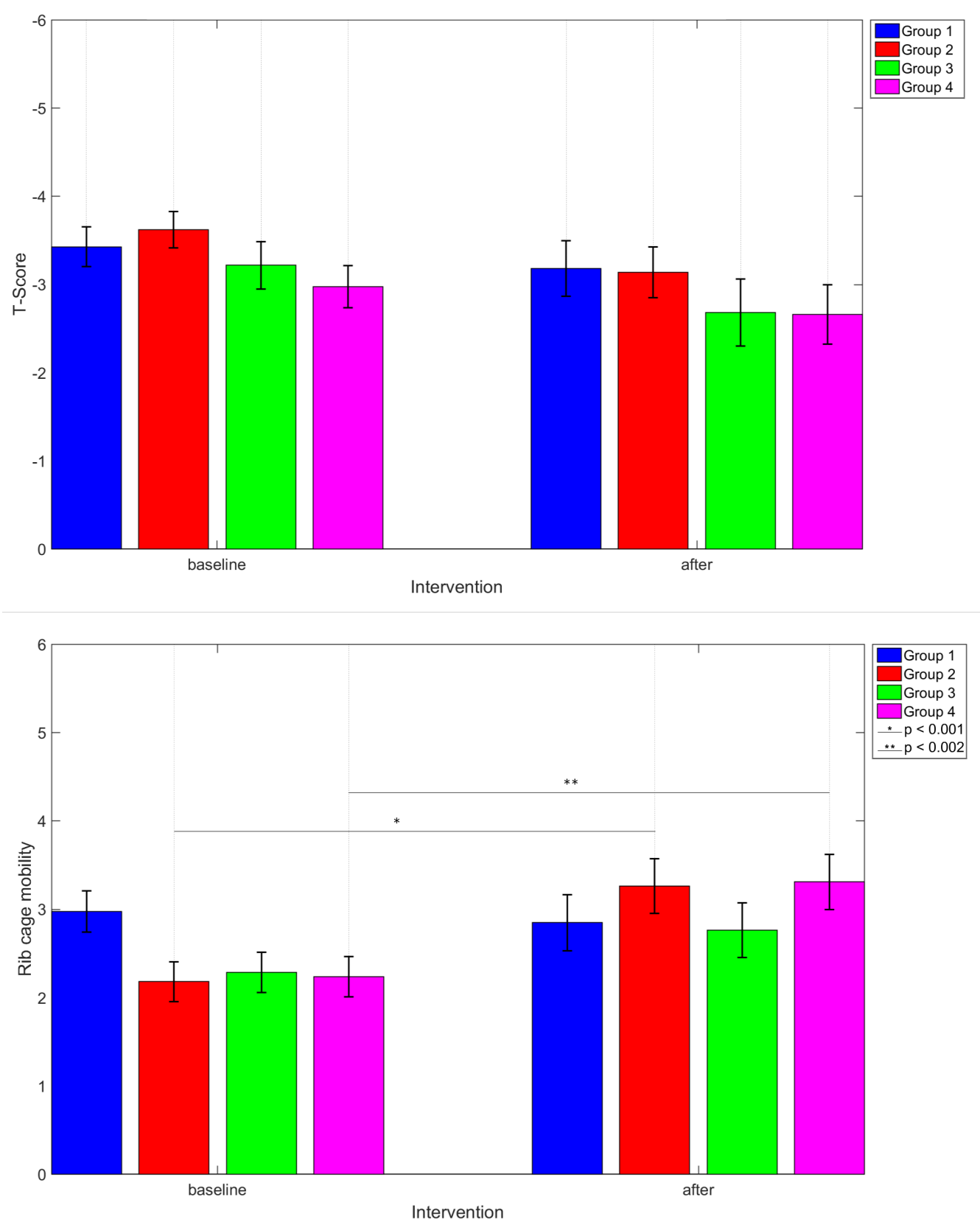

Fig. 2. Bone density at baseline and after intervention, by group

The length of the whiskers represents the standard error (SE) of the group's mean.
Fig. 3. Rib cage mobility at baseline and after intervention, by group

The length of the whiskers represents the standard error (SE) of the group's mean.

\section{The effect of intervention on locomotor activity}

Twelve months of physical exercises proved insufficient for the study participants to reach 3,500-5,500 steps per day, which is recommended for chronically ill people aged $\geq 65$ years (Fig. 4). ${ }^{15}$

ANOVA showed that the effect of the type of therapy $(\mathrm{p}<0.029)$, of the order of examination $(\mathrm{p}<0.000)$ and of the interaction between them $(\mathrm{p}<0.000)$ were significant (Table 1).

Bonferroni's post-hoc test revealed that locomotor activity (i.e., the daily number of steps) improved statistically significantly after intervention in groups $3(\mathrm{p}<0.000)$ and $4(\mathrm{p}<0.000)$. In the control group, it was statistically significantly worse $(\mathrm{p}<0.005)$ (Fig. 4).

Table 1. ANOVA results

\begin{tabular}{|c|c|c|c|c|c|c|c|c|}
\hline \multirow{2}{*}{ Effect } & \multicolumn{2}{|c|}{ Bone density } & \multicolumn{2}{|c|}{ Rib cage mobility } & \multicolumn{2}{|c|}{ Locomotor activities } & \multicolumn{2}{|c|}{ Motor abilities } \\
\hline & $f$ & $p$-value & $f$ & $p$-value & $f$ & $\mathrm{p}$-value & $f$ & $p$-value \\
\hline Therapy & 1.165 & 0.331 & 0.444 & 0.722 & 3.155 & 0.029 & 4.716 & 0.004 \\
\hline Order of examination & 9.957 & 0.003 & 23.475 & 0.000 & 25.618 & 0.000 & 0.582 & 0.448 \\
\hline Interaction & 0.300 & 0.825 & 4.878 & 0.004 & 29.103 & 0.000 & 9.984 & 0.000 \\
\hline
\end{tabular}



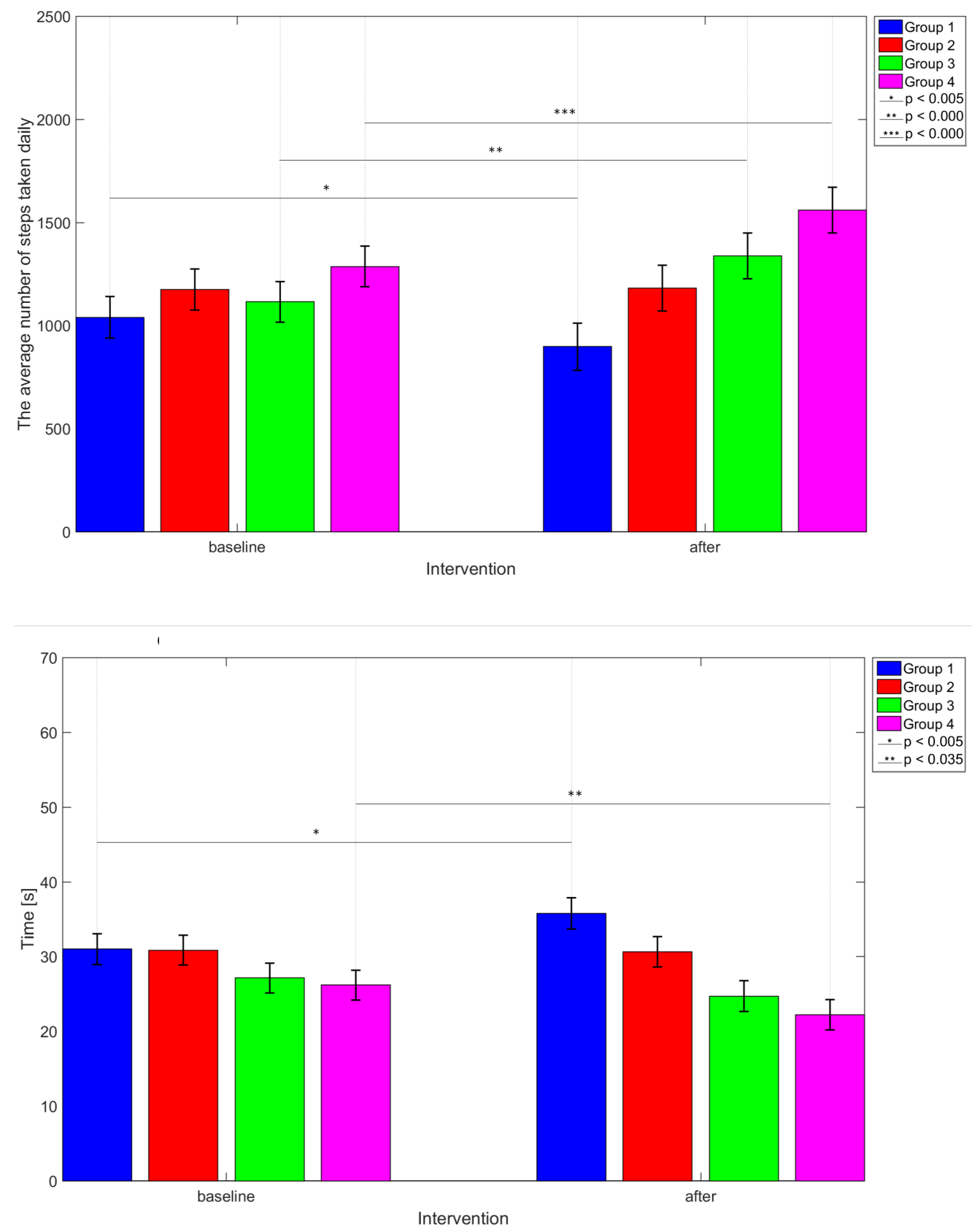

Fig. 4. Average number of steps taken daily by the participants at baseline and after intervention, by group

The length of the whiskers represents the standard error (SE) of the group's mean.
Fig. 5. Groups' scores on the Timed Up \& Go Test at baseline and after intervention

The length of the whiskers represents the standard error (SE) of the group's mean.

\section{The effect of intervention on motor abilities}

After 12 months of intervention, all exercise groups scored higher on the Timed Up and Go Test, but the control group's scores were worse than at baseline (Fig. 5).

ANOVA showed that the effect of the type of therapy and interaction were statistically significant $(\mathrm{p}<0.004$ and $\mathrm{p}<0.000$, respectively) (Table 1 ).

The results of Bonferroni's post-hoc test revealed significant improvement in group 4, who completed the TUG test in significantly less time $(\mathrm{p}<0.035)$. However, the scores of group 1 (controls) were significantly worse than at baseline $(\mathrm{p}<0.005)$ (Fig. 5).

\section{The effect of intervention on the risk of falls}

Participants' scores on the post-intervention TUG test showed a considerably lower risk of falls in group 4, a slightly higher risk in groups 1 and 2 and the same risk in group 3 (maximum likelihood $X^{2}\left(\mathrm{ML} X^{2}\right)$ of 9.473; $\mathrm{p}=0.148$ ) (Fig. 6).

Participants' scores obtained on the FRT were consistent with their scores on the TUG test $\left(\mathrm{ML}^{2}\right.$ of 8.42; $\left.\mathrm{p}=0.20\right)$ (Fig. 7).

Participants' scores on the post-intervention TUG test showed that $90 \%$ of women in group $1,90.5 \%$ in group 2 , $61.9 \%$ in group 3 , and $52.4 \%$ in group 4 were at risk of falls. The ML $X^{2}$ value revealed that the differences between 

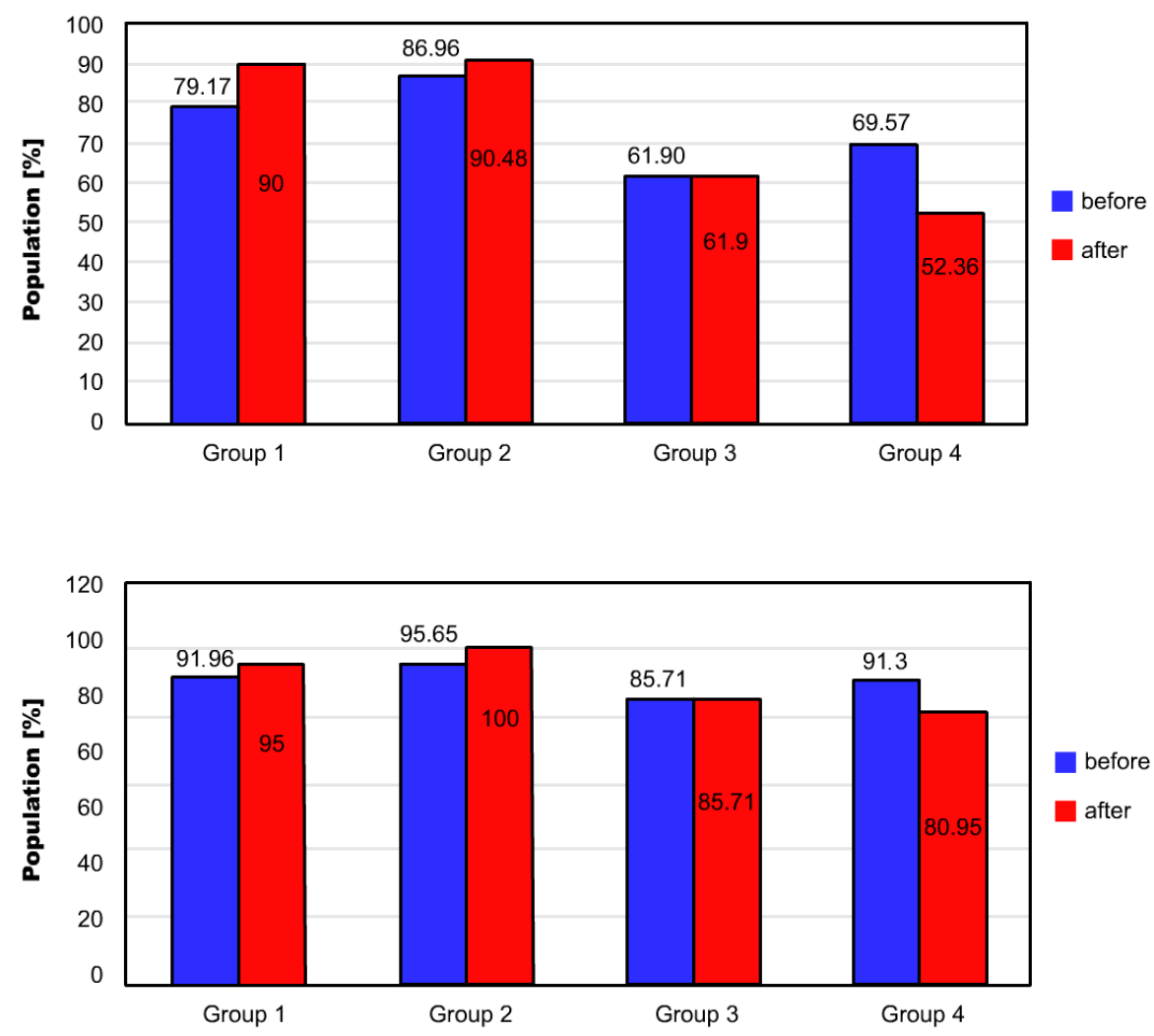

Fig. 6. Risk of falls at baseline and after intervention according to the Timed Up \& Go Test scores
Fig. 7. Risk of falls at baseline and after intervention according to the Functional Reach Test scores these rates were statistically significantly different $\left(\chi^{2}\right.$ value of 12.80; $\mathrm{p}=0.00)$, in contrast with those calculated at baseline ( $\chi^{2}$ value of $4.33 ; \mathrm{p}=0.22$ ).

The FRT scores obtained post-intervention were similar, but the ML $\chi^{2}$ test did not show the risk of falls to be statistically significantly different between the groups $\left(x^{2}\right.$ value of 7.012; $\left.\mathrm{p}=0.07\right)$

\section{Discussion}

Many studies provide evidence that anti-osteoporotic therapy is more effective in groups that also do physical exercises than in groups where physical activity is not increased. ${ }^{17,18}$ In the study by Simkin and Ayalon, 14 women aged 53-54 years participated in a 5-month program of bone strengthening exercises. The bone density measurements performed at month 6 showed that in the exercise group, bone density level was greater by almost $4 \%$, while in the control group it had decreased by $2 \%{ }^{11}$ Dalsky et al. studied 2 groups of post-climacteric women, 1 of which exercised for 22 months while the other (controls) abstained from exercise. In the exercise group, bone mass increased by $6.1 \%$, but in the control group no changes in BMD were noted. ${ }^{19}$ According to Ishimi's recent article, secondary prevention of osteoporosis must be accompanied by an essential change in lifestyle, including a new approach to nutrition, physical activity, smoking, and alcohol intake. ${ }^{20}$ In the review article on Nordic walking that Opara has published recently, the health benefits that the activity offers include improved gait efficiency, coordination and postural stability. Most importantly, however, Nordic walking reduces the risk of falls which in the case of osteoporotic patients can have extremely painful consequences. ${ }^{21}$

Weber-Rajek et al. indicated in their review report that while the whole-body vibration exercise could be recommended for the management of postmenopausal osteoporosis, it could not replace pharmacological and dietary therapies. ${ }^{22}$ Hakestad et al., working for the OsteoACTIVE program, reported that exercises with weight vests and a patient education program were effective in the case of women with osteopenia and a healed wrist fracture. ${ }^{23}$

Most studies on osteoporosis recommend walking in addition to other physical exercises. Dawson-Hughes et al. established that post-climacteric women walking approx. 1 mile per day had higher bone density than those walking shorter distances. ${ }^{24}$ This observation was supported by Shangold, who found bone density to be higher and more stable in people walking several kilometers per day. ${ }^{25}$ In the Pindel and Pluskiewicz study, the only effective exercise was a brisk walk with an additional load applied to the spine. ${ }^{26}$ Bonaiuti et al. reported that in participants who walked 20-25 min every day covering a distance of $1-2 \mathrm{~km}$, mineral bone density improved. ${ }^{27}$

One of the aims of this study was to establish whether Nordic walking and modified Sinaki exercises would have an effect on the participants' BMD. The results are less optimistic than those presented above. Bone density improved 
not only in the 3 exercise groups but also in the control group. Intervention was most effective in groups 2 and 3 (T-score higher by 0.5 ) and group 4 (0.3). In the control group, $\mathrm{T}$-score improved by as little as 0.2 . The intergroup differences were not statistically significant, probably because of bone density being measured at the distal radial bone and not at the lumbar spine, which is more suitable for monitoring the course of treatment. In none of the 4 groups did bone density change statistically significantly. Smidt also failed to find statistically significant differences between women doing resistance exercises 3 times a week over a period of 12 months and those who did not exercise (bone mass decreased in both groups). ${ }^{28}$ The higher postintervention BMD values in this study's exercise groups and control group imply that bone density was mainly determined by pharmacological treatment, which was the same in all groups. Cukras and Jegier reported that although regular physical activity could slow down skeletal demineralization in people over 50 years of age, it was less effective than anti-osteoporotic drugs. They concluded that physical activity should be used as an enhancement of nutritional therapy and pharmacotherapy rather than as primary treatment for people with low BMD. ${ }^{29}$

According to many researchers, regular physical activity offers elderly people with osteoporosis more health benefits than a moderate increase in bone density alone. These benefits include better respiratory function, greater independence in everyday activities and improved physical and mental function. Of equal importance is the fact that physical activity increases muscle strength, endurance, balance, and motor control, thus reducing the risk of falls and fractures. . $^{3,30}$

In this study, 12 months of regular physical exercises significantly improved rib cage mobility in groups 2 and 4 (by $1.1 \mathrm{~cm}$ ). The $0.5 \mathrm{~cm}$ increase noted in group 3 was not statistically significant, and in group 1 (controls), rib cage mobility decreased by $0.1 \mathrm{~cm}$. According to Roczniak et al., respiratory exercises and exercises stretching the intercostal muscles can help preserve or increase rib cage mobility in osteoporotic patients. ${ }^{31}$ The results of this study lead to the same conclusion, because rib cage mobility improved only in groups 2 and 4, the ones who did modified Sinaki exercises including the abovementioned exercises.

Elderly people are assessed for the risk of a fall by means of the Timed Up and Go Test and the Functional Reach Test measuring their motor abilities and postural balance. A review of studies provided conflicting information on whether physical exercises can improve performance in these tests. In the study that Żak et al. carried out with 28 residents of a Chorzów RFC, after 12 months of a fall prevention program, $29 \%$ of the participants had less difficulty rising from a chair, 67\% performed as before and $4 \%$ reported that the TUG test was more difficult for them. The results were statistically significant. ${ }^{32}$ In the study by Kozak-Szkopek and Galus, 22 females (aged 72-88 years) living in a care facility for retired health care personnel in Warszawa participated in a 2-month rehabilitation program made up of individual and group exercises (general fitness and breathing exercises, also stretching exercises with the Tri-Gym ${ }^{\mathrm{TM}}$ device; KOO Medical, Shanghai, China) that were done for $30 \mathrm{~min}, 3$ times a week. The program reduced the average time the participants took to complete the TUG test from $12.41 \mathrm{~s}$ to $11.27 \mathrm{~s}$. However, the difference was not statistically significant $(\mathrm{p}=0.06){ }^{33}$ The results that Ballad et al. obtained in a study with 2 groups of 20 women aged $>65$ years (the intervention group and the control group) were not statistically significant, either. The first of them exercised for $1 \mathrm{~h}, 3$ times a week over a period of 15 months. The average results each group achieved in the FRT performed at baseline and after intervention were not statistically significantly different from each other $(10.5 \mathrm{~cm}) .{ }^{34}$ In the Mętel et al.'s study, the exercise group that did sensorimotor exercises twice a week did not perform significantly better than controls on the FRT and TUG tests. The authors concluded that the most likely reason why the tests failed to show the expected positive changes was the physical fitness of the participants in the exercise group. ${ }^{35}$

In our study, after 12 months of modified Sinaki exercises and Nordic walking, all 3 exercise groups took less time to complete the TUG test. Group 4 was statistically significantly faster than at baseline (by $4 \mathrm{~s} ; \mathrm{p}<0.035$ ), and groups 2 and 3 were slightly faster (by $0.2 \mathrm{~s}$ and $2.5 \mathrm{~s}$, respectively), but the differences were not statistically significant. Group 1 (controls) performed significantly worse than at baseline (by $4.8 \mathrm{~s} ; \mathrm{p}<0.005$ ). The FRT performed post-intervention showed that postural balance improved statistically insignificantly in groups 4 and 3 (as indicated by functional reach increasing by $7.8 \mathrm{~cm}$ and $0.9 \mathrm{~cm}$, respectively). It is likely that the results would have been better had the modified Sinaki exercises and Nordic walking programs been enhanced by static and dynamic balance exercises, exercises with balance discs and training in getting up after a fall. The same conclusion was reached by Żak et al., who conducted a study with 46 persons aged 78-86 years suffering from gait disorders and impaired mobility. At baseline, it took them from 21 to $30 \mathrm{~s}$ to complete the TUG test (as in our study). The intervention consisted of rehabilitation exercises (the same as we used), postural balance exercises and training in walking safely. Participants exercised at home for $45 \mathrm{~min}, 3$ times a week for a period of 12 months. After intervention, $62.5 \%$ of them completed the TUG test in $11-20 \mathrm{~s}$ ( $\mathrm{p}<0.004) .{ }^{36}$ Wnuk et al. studied 30 osteoporotic patients aged $60-80$ years with impaired physical fitness and balance disorders. In addition to doing exercises used in the earlier studies (stretching and strengthening exercises, resistance exercises with flexible bands, circulation, breathing and relaxation exercises, etc.), they also exercised while sitting on balance discs and walked backwards on a treadmill. ${ }^{37}$ The intervention significantly improved their performance on the FRT and TUG tests. 
There are studies according to which the postural balance of people with reduced bone mass can also be improved by Tai Chi training. Evidence of this has been provided by Maciaszek et al., who studied the effect of 18 weeks of Tai Chi training on postural balance and risk of falling. The study involved 49 males aged $60-82$ years of age diagnosed with osteopenia or osteoporosis. They were divided into an exercise group $(n=25)$ that did Tai Chi twice a week for $45 \mathrm{~min}$ and a control group $(\mathrm{n}=24)$. Body balance measurements were made with the Computer Posturographic System PE 90 (Natus Medical Inc., Pleasanton, USA). The measurements were also an opportunity to analyze the participants' ability to perform specific balance tasks (by measuring deflections in the set scope and direction). Intervention increased the effectiveness of balance task performance $(\mathrm{p} \leq 0.01)$ in the Tai Chi group from $80.95 \%$ to $84.45 \%$, while in the control group, a statistically significant improvement in the level of body balance was not noted. ${ }^{38}$

This study also sought to establish the effect of 12 months of Sinaki exercises and Nordic walking on the number of steps the study participants took per day. Bonferroni's post-hoc test showed a statistically significant increase in the number of steps in groups $3(\mathrm{p}<0.000)$ and $4(\mathrm{p}<0.000)$, and a significant reduction in the control group $(\mathrm{p}=0.005)$. Not a single participant reached the level of 3,500-5,500 steps per day, which is recommended for chronically ill persons aged $\geq 65$ years. ${ }^{13}$ The highest statistically significant increase in the number of steps was observed in group 4 (272.3 steps). In the Fitzpatrick et al.'s study with 418 elderly persons (mean age of 75 years), 4 months of chair exercises and walking increased the daily number of steps by $29 \%$ ( $\mathrm{p} \leq 0.0001)$ and extended the duration of physical activity by $26 \%$ ( $\mathrm{p} \leq 0.001)$. The authors also noted that with the increased locomotor activity of the study participants, their physical fitness improved. ${ }^{39}$

\section{Conclusions}

The results of the study allow the following conclusions to be drawn:

- the program of modified Sinaki exercises performed twice a week for 12 months statistically significantly increased rib cage mobility and insignificantly improved motor abilities and bone density in the elderly women with reduced bone mass participating in the study;

- the Nordic walking program, during which participants exercised with the same frequency as above, statistically significantly increased their locomotor activity, while the improvement in motor abilities, bone density and rib cage mobility was not statistically significant;

- the program combining modified Sinaki exercises and Nordic walking that the study participants performed 4 times a week for a period of 12 months proved the most effective therapeutically; it statistically significantly increased their motor abilities, rib cage mobility and locomotor activity, and it improved bone density and reduced the risk of falls, though not significantly;

- in the control group, measurements performed after 12 months of intervention revealed statistically insignificantly higher bone density, significantly lower locomotor activity and insignificantly decreased rib cage mobility and motor abilities, while the risk of falls was higher than at baseline.

\section{References}

1. Badurski J, Czerwiński E, Marcinowska-Suchowierska E. Osteoporoza - ocena ryzyka złamania. Status Quo Arte Anno 2007/2008: Przegląd stanowisk Światowej Organizacji Zdrowia (WHO), Europejskiej Agencji Medycznej (EMEA), Europejskiego Towarzystwa Klinicznych i Ekonomicznych Aspektów Osteoporozy (ESEAO), Międzynarodowej Fundacji Osteoporozy (IOF), Polskiej Fundacji Osteoporozy (PFO) i Polskiego Towarzystwa Osteoartrologii (PTOA). Post Nauk Med. 2008;21(6):335-359.

2. Sran MM, Karim M, Khan KM. Physiotherapy and osteoporosis: Practice behaviors and clinicians' perceptions - A survey. Manual Therapy. 2005;10:21-27.

3. Yamazaki S, Ichimura S, Iwamoto J, et al. Effect of walking exercise on bone metabolizm in postmenopausal women with osteopenia/ osteoporosis. J Bone Miner Metab. 2004:22:500-508.

4. Hansen L. Nordic walking does not reduce the loading of knee joint. Skan J Med Sci Sports. 2008;18:436-441.

5. Suija K. Physical activity of depressed patients and their motivation to exercise: Nordic walking in family practice. Int $J$ Rehabil Res. 2009;32(2):132-138.

6. Morgulec-Adamowicz N, Rutkowska I, Rekowski W, et al. Aktywność fizyczna osób starszych w Uniwersytecie Trzeciego Wieku w Polsce. Post Rehab. 2010;24(2):73-80.

7. Bello M, Cirilo Cousa M, Neto G, et al. The effect of a long-term, community-based exercise program on bone mineral density in postmenopausal women with pre-diabetes and type 2 diabetes. J Human Kinetics. 2014;43:43-48.

8. Sinaki M. Exercise and osteoporosis. Arch Phys Med Rehab. 1989,70(3): 220-229.

9. Sinaki M, Khosia S, Limburg PJ. Muscle strength in osteoporotic versus normal women. Osteoporosis Int. 1993;3:8-12.

10. Izquierdo M, Gonzalez-Badillo JJ, Häkkinen K, et al. Effect of loading on unintentional lifting velocity declines during singles sets of repetitions to failure during upper and lower extremity muscle actions. Int J Sports Med. 2006;27:718-724.

11. Simkin E, Ayalon J. Osteoporoza, zapobieganie i zwalczanie ruchem. Warszawa: SIC; 1996.

12. Nawrat-Szołtysik A, Opara J, Kucio C. Własna modyfikacja ćwiczeń według Mehrsheed Sinaki w osteoporozie u osób starszych. Rehabil Prakt. 2011;5:27-32.

13. Siggeirsdóttir $\mathrm{K}$, Jónsson BY, Jónsson $\mathrm{H} J$ Jr, Iwarsson S.The timed 'Up \& Go' is dependent on chair type. Clin Rehabil. 2002;16(6):609-616.

14. Żak M. Physical rehabilitation of geriatric patients with gait and functional disorders. Adv Rehabil. 2005;1:37-40.

15. Tudor-Locke C. Taking steps toward increased physical activity: Using pedometers to measure and motivate. Res Digest. 2002;3(7):1-8.

16. Wolff I, Croonenborg I, Temper HCG, et al. The effect of exercise training programs on bone mass: A meta-analysis of published controlled trials in pre-and postmenopausal women. Osteoporosis Int. 1999;9:1-2.

17. Tan AM, Lamontage AD, Sarmugan R, et al. A cluster-randomised, controlled trial to assess the impact of a workplace osteoporosis prevention intervention on the dietary and physical activity behaviours of working women: Study protocol. BMC Public Health. 2013;29(1): 405-416.

18. Bravo G, Gauthier P, Roy P, et al. Impact of 12 -month exercise program on the physical and psychological health of osteoporosis women. J Am Geriatr Soc. 1996;44(7):756-762. 
19. Dalsky GP, Stocke KS, Ehsani AA, Slatopolsky E, Lee WC, Birge SJ Jr. Weight-bearing exercise training and lumbar bone mineral content in postmenopausal women. Ann Intern Med. 1998;108: 824-828.

20. Ishimi Y. Osteoporosis and lifestyle. J Nutr Sci Vitaminol (Tokyo). 2015; 61(S):139-141.

21. Opara J. Nordic walking w zapobieganiu upadkom. In: Czerwiński E, ed. Osteoporoza. Problem interdyscyplinarny. Warszawa: PZWL; 2015:229-235.

22. Weber-Rajek M, Mieszkowski J, Niespodziński B, Ciechanowska K. Whole-body vibration exercise in postmenopausal osteoporosis. Prz Menopauz. 2015;14:41-47.

23. Hakestad KA, Torstveit MK, Nordsletten L, Risberg MA. Effect of exercises with weight vests and a patient education programme for women with osteopenia and a healed wrist fracture: A randomized, controlled trial of the OsteoACTIVE programme. BMC Musculoskelet Disord. 2015;16(1):352-360.

24. Dawson-Hughes B, Jacques $P$, Shipp C. Bone density of the radius, spine and hip inrelation to percent ideal body weight in postmenopausal women. Calcif Tissue Int. 1987;40:310-314.

25. Shangold MM. Exercise and menopause. Phys Sports Med. 1998;26(12): 45-59.

26. Pindel B, Pluskiewicz W. Rola wysiłku fizycznego w zapobieganiu i leczeniu osteoporozy. Pol Tyg Lek. 1993;48(37/49):780-781.

27. Bonaiuti $D$, Shea B, Lovine $R$, et al. Exercise for preventing and treating osteoporosis in postmenopausal women. Cochrane Database Sys Rev. 2002;3:333-339.

28. Smidt GL. The effects of high-intensity trunk exercise on bone mineral density of postmenopausal women. Spine. 1992;17(3): 280-285.

29. Cukras Z, Jegier A. Aktywność fizyczna a gęstość mineralna kości - aktualny stan wiedzy. Pol Arch Med Wew. 2005;113(2):164-171.
30. Kemmler W. Exercise effects on bone mineral density, falls, coronary risk factors, and health care costs in older women: The randomized controlled senior fitness and prevention (SEFIP) study. Arch Int Med. 2010;70(2):179-185

31. Roczniak W, Babińska-Roczniak M, Roczniak A, et al. Zalecenia rehabilitacyjne dla pacjentów z osteoporozą. Probl Med Rodz. 2011;13(3): 35-42.

32. Żak M, Melcher U. Rehabilitacja jako element programu zapobiegania upadkom osób starszych. Przegl Lek. 2002;59:4-5.

33. Kozak-Szkopek E, Galus K. Wpływ rehabilitacji ruchowej na sprawność psychofizyczną osób w podeszłym wieku. Gerontol Pol. 2009; 17(2):79-94.

34. Ballad JE, McFarland C, Wallace LS, Holiday DB, Roberson G. The effect of 15 weeks of exercise on balance, leg strength, and reduction in falls in 40 women aged 65-89 years. J Am Med Womens Assoc. 2004;59:255-261.

35. Mętel S, Milert A, Szczygieł A, et al. Wpływ 6-miesięcznego treningu sensomotorycznego na sprawność funkcjonalną osób starszych z przewlekłym bólem krzyża. Post Rehab. 2010;24(3):51-65.

36. Żak M, Skalska A, Szczerbańska K. Programy nauki samodzielnego podnoszenia się po upadku dla osób starszych - badanie randomizowane. Ortop Traumatol Rehabil. 2008;10(5):491-502.

37. Wnuk B, Walusiak M, Durmała J, et al. Wpływ fizjoterapii rozszerzonej o różne formy treningu chodu na bieżni ruchomej na sprawność funkcjonalną osób starszych zagrożonych upadkiem. Fizjoterapia. 2010;18(2):3-9.

38. Maciaszek J, Osiński W, Szeklicki R. Effect of Tai Chi on body balance: Randomized controlled trial in men with osteopenia or osteoporosis. Am J Chin Med. 2007;35(1):1-9.

39. Fitzpatrick SE, Reddy S, Lommel TS, et al. Physical activity and physical function improved following a community-based intervention in older adults in Georgia senior centers. J Nutr Elder. 2008;27:1-2. 